U.S. Department of the Interior, Geological Survey Spring 1978

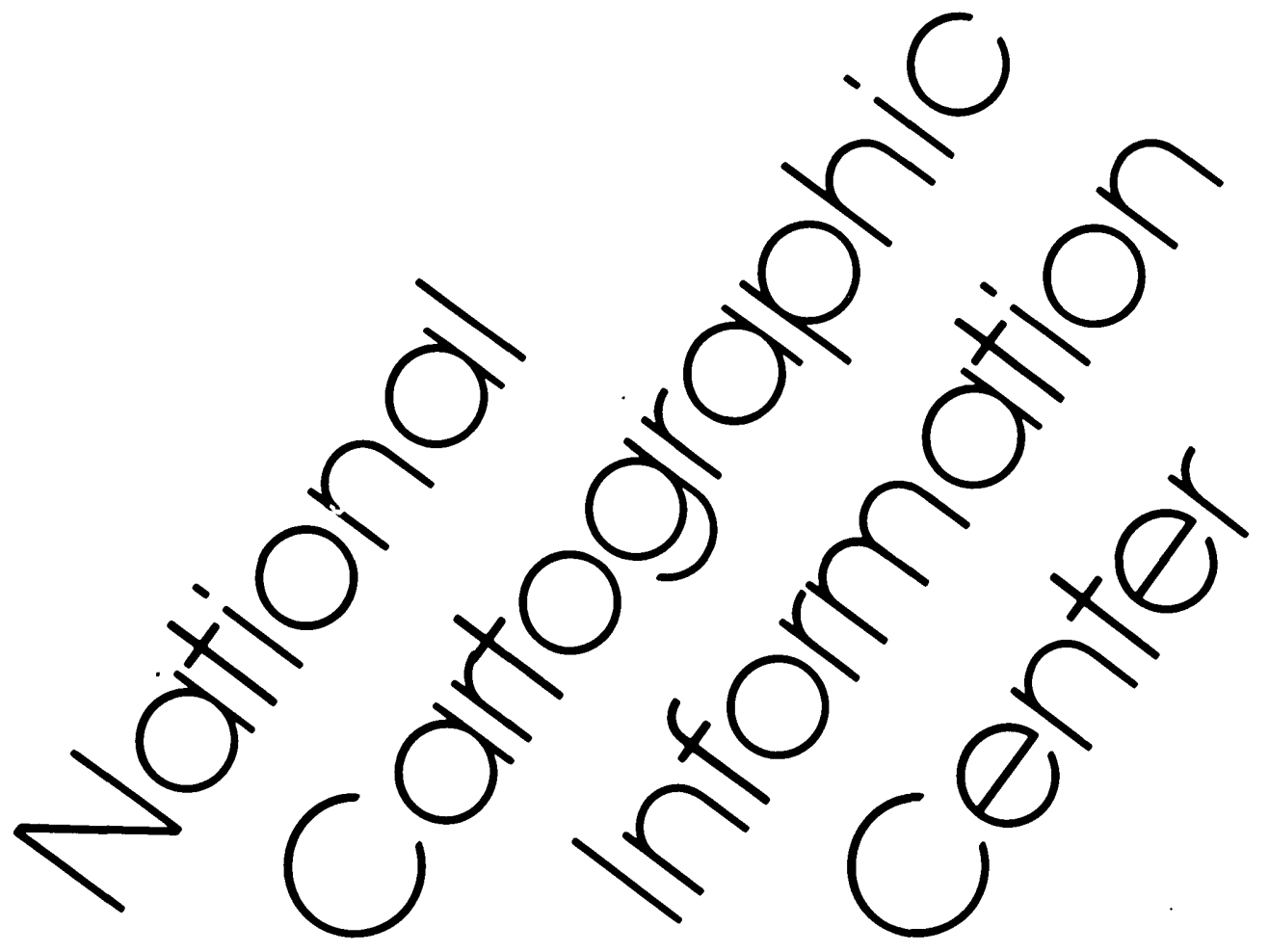



U.S. Geological Survey

507 National Center

Reston, Virginia 22092

703-860-6045

No. 8/spring 1978

Editor's notes

$\mathrm{Hi}$, it's late springtime. The irises are blooming, the weather has stopped being either (1) freezing or (2) wet, and as a result the map-using business is picking up.

Since no one wrote in complaining about receiving mangled newsletters, we're continuing our policy of mailing them envelopeless. The editor sent one to her own home and received it in perfect condition except for the toothmarks and one paw print incurred when her dog fetched it from the mailbox.

Next on the list of notes, we ran the wrong address in the last issue for ordering the Landsat Index Atlas of the Developing countries of the world. The publisher and distribution point is the Johns Hopkins University Press, Baltimore, Md. 21218, not the USGS Branch of Distribution.

In this issue we cover several interesting topics, including a report on the $\mathrm{NCIC/Special} \mathrm{Libraries} \mathrm{Association} \mathrm{meeting} \mathrm{in} \mathrm{Den-}$ ver, the launching of a third Landsat satellite with a new thermal band, and the formation of a new California map society.

We're also about ready to update our computerized address file. If we are sending you duplicates, or you need an address correction, please take a moment and send us your mailing label with the changes clearly marked. 


\section{CARTOGRAPHIC NEWS}

\section{Maps of coal resources data}

The Geological Survey recently let a series of contracts for studying and mapping western U.S. coal regions. The idea behind the contracts is to update and present in a new, improved format, the information used to classify federally-owned coal resources. Some of the map overlays will show such information as the location of specific ground points and the thickness of individual coal beds and overburden at those points; the geologic structure of coal beds; coal outcrop areas; existing coal mines, prospects, ana boreholes; and various resource and political boundaries. Another overlay series will indicate various degrees of coal development potential. All of this interesting information will be compiled on overlays keyed to 7.5-minute USGS quadrangle maps and will be accompanied by written reports summarizing the new data. A total of 403 quadrangles are to be mapped over the States of Wyoming, Montana, Colorado, New Mexico, Utah, and North Dakota. The maps and accompanying reports will be available for sale as they are completed.

\section{Launching of third Landsat satellite}

On March 5, NASA launched the third Landsat Earth resources satellite. Similar to the previous two, Landsat 3 circles the earth 14 times a day in a polar orbit. Landsat 3 also carries two imaging systems, a multispectral scanner (MSS) with green, red, and two near-infrared bands and a pair of return beam vidicon (RBV) television) cameras. A new feature on Landsat 3 is the addition of a fifth MSS band (band 8), in the thermal range of the electromagnetic spectrum (10.4 to 12.6 micrometers). This thermal infrared band will be used to collect nighttime temperature data. The area imaged by band 8 is 115 by 115 miles, the same as bands 4-7. Higher resolution ( 40 meters) RBV imagery from Landsat 3 is expected to be twice as sharp and clear as that from earlier Landsats. However, it will take four RBV panchromatic images to cover the same area as one MSS scene.

In an additional note, an all-digital system for processing Landsat data will be installed by NASA and USGS later this year. This system will improve data quality and shorten delivery time to users.

To learn more about the satellites, contact the EROS Data Center at Sioux Falls, S.Dak. 57198, or any NCIC office (see address list page 9). 
USGS planning series of State earthquake maps

The Geological Survey's National Earthquake Information Service (NEIS) in Golden, Colo., is compiling a series of 48 State maps depicting the history of earthquake activity in each State. The map series will tell the location, date, time of day, latitude and longitude, severity and area over which each tremor or earthguake was felt. The maps are fairly basic, each showing the outline of a State, its major cities, and identifying neighboring States or countries. Triangles are used to mark earthquake sites and near each triangle are listed the maximum earthquake intensity recorded for the site (using Modified Mercalli Scale) and the year with the most earthquake activity.

The series is expected to be finished sometime in 1978. The first map, of Maine, is already available through the Eranch of Distribution, USGS, 1200 South Eads St., Arlington, Va. 22202 (75фદ, prepaid).

Space imagery--Landsat and Skylab micrographic indexes

The Eros Data Center (EDC) has developed a micrographic index system for Landsat and Skylab data. Storing information on 105 by $148 \mathrm{~mm}$ (4 $\times 6$ inch) microfiche, the system is an inexpensive way to give users easy access to computerized data describing Landsat records imaged since the first launching. An updating schedule has been built into the system to keep the information current.

The organization of the microfiche records is based on the Worldwide Reference System (WRS), a notation system of paths and rows which are used to reference Landsat images. Individual microfiche are path oriented (i.e., each record cescribes only one path) with each microfiche containing data on 60 wRS row intersections along a particular path.

The Skylab indexing system is keyed to plot maps of the United States on which satellite passes are noted and photo centers are plotted. (Indexing is by camera system and mission.)

Both reference systems are a joint effort of NCIC and the EROS Data Center. Copies of these indexes can be viewed at the NCIC offices and will be available for sale later this spring. A subscription service will be offered for purchasing complete world coverage or coverage of smaller geographic areas. 
NCIC NEWS

NCIC/SLA Denver meeting

Traveling by plane, bus, car, and "prairie schooner", members of the Special Libraries Association's Geography and Map Division arrived in Denver on March 9 for a two-day meeting on NCIC and the Ceological Survey's National Mapping Program. The conference was hosted by USGS's Rocky Mountain Mapping Center. The highlight of the first day was a special hands-on briefing on products of the National Mapping Program presented by the people from the center who actually make the products. This was followed by a spirited session on problems related to map distribution and depository agreements. You map librarians who didn't attend can be assured that your colleagues made their feelings quite evident.

During the afternoon and morning sessions on March 9 and 10, we all learned more about NCIC than we thought we needed to know with presentations by representatives of the national, regional, and State NCIC offices and the EROS Data Center. On Friday, following a series of discussion-group presentations and a conference summary, the group toured the mapping center and the map distribution center.

From the cards and letters that are coming in, it looks like the meeting was a success. The Geological Survey gained a deep respect for the role map librarians play, and we realize that through map librarians NCIC has an active group of affiliates. We intend to strengthen our relationship and involve the membership of the SLA Geography and Map Division in our programs and activities.

Gary North

Chief, NCIC

NCIC's new dimension

NCIC's sudden entry into regional and State-level affiliations (see newsletter 7) has caused some administrative and logistical challenges for the Reston office. To organize information coordination, equipment, publications, and even day-to-day comunications between 5 regional offices, several branches, and the projected 50 State 
offices, NCIC established a new position, Assistant for NCIC Operations. In his inaugural address, delivered from behind his swamped desk, George Madill defined his role in life as being coordinator of training and developer of training aids; the man who evaluates products and services; overseer of the distribution of hard copy, micrographic, and electronic information and product samples; a central contact for resource information regarding office operations; a monitor of the activities of NCIC offices; and an artful doager of numerous other tasks which staffers have now labeled "Let George do it".

Now that we know what Mr. Madill is doing, the question might reasonably arise as to why NCIC is in the affiliation business at all. Simply because NCIC was set up to hunt for, organize, make sure people knew of, and then distribute information about cartographic products. The United States covers a large amount of territory, territory that has been surveyed, mapped, and photographed countless times for countless reasons. No one central office could find everything, catalog it, and keep files up to date. So enter the affiliates, who are primarily state offices, of ten designated by the governor. NCIC distributes (or will distribute) micrographic indexes--cross-referenced lists of the information in the EROS Data Center Main Image File, the Aerial Photography Summary Record System file, the Map and Chart Information System file, etc.--micrographic records of the USGS topographic map series, and references to contacts, brochures, and other aids to each affiliate. With these reference tools, a user will be able to get information about a wide array of aerial photographs, space images, or maps.

The affiliates, and in turn their customers, will have access to a national data base of cartographic information. NCIC benefits by using the affiliates to fill in the gaps of NCIC's inventory of existing cartographic data within their State and to find new sources of data. This information is then shipped to NCIC-Reston for inclusion in the national data bases. The States and the public benefit by having rapiō access to cartographic data that may never have been inventoried before.

REGIONAL NCIC NEWS

NSTL/NCIC and the Corp of Engineers

Recently, the NCIC office at the National Space Technology Laboratories in Mississippi arranged for the Mobile District Corps of Engineers to enter information about their aerial photographic 
projects into NCIC's Aerial Photography Summary record System (APSRS). Hank Svehlak of NCIC/NSTL and Fred Klinefelter of Eastern Mapping Center NCIC instructed the Corps on APSRS's coding techniques.

The Corps has flown photographic projects over many parts of Alabama, Georgia, Mississippi, and northwest Florida. Information about their holdings, including scale, dates, cloud cover, and numerous other descriptive items, should be appearing soon in the APSRS catalogs. Copies of the photographs can be obtained from the Corps of Engineers Office, Mobile District, Mobile, Ala.

Hank Svehlak

Chief, NSTL/NCIC

PUBLICATONS

New Landsat Data Users Handbook

NASA and the EROS Data Center are preparing a new edition of the Landsat Data Users Handbook. The old handbook is being revised to describe the changes in Landsat products caused by new digital processing systems and the addition of thermal data and high-resolution RBV data from the just-launched Landsat 3. The updated Landsat handbook will be released sometime this summer and will have a looseleaf format. Cost per copy will be between $\$ 20$ and $\$ 30$.

\section{Landsat newsletter}

An easier item to get your hands on at the present moment is an issue of the Landsat Newsletter published by NASA. This newsletter was started to inform Landsat data users of the latest changes in remote sensing technology, and it appears irregularly. Recent issues have covered such matters as new Landsat products, reports, program reviews, adjustments to satellite orbits, and meetings of remote sensing aficionados. You can get on the mailing list for the newsletter (no charge for a subscription) by contacting the Landsat Newsletter, Code 902.6, NASA-GSFC, Greenbelt, Md. 20771. Telephone 301-982-6095. 
Biblio--University of Illinois, Map and Geography Library newsletter

The Map and Ceography Library of the University of Illinois at Urbana-Champaign publishes a highly useful newsletter entitled "Biblio." The Library lists, at the front of each issue, the maps and cartography-related books it has acquired since the last newsletter and then proceeds into a section of news and notes. These ran the gamut, in issue 6 , from excitement over a hookup into the famed Ohio College Library Catalog (OCLC) computer data base of map listings to delight over a new icosahedron ( 20 sided) earthquake globe available from the National Geophysical and Solar-Terrestrial Data Center in Colorado.

The newsletter is well-written, and a number of the articles fascinating. If you are interested in more information or a subscription, contact the the Map and Geography Library at the University of Illinois, Urbana, Ill. 61801.

MEETINGS AND CONVENTIONS

New California map society

The first meeting of the Map Society of California was held on Saturday May 20, at the University of California Berkeley campus. Organizers behind the new society are Fhilip Hoehn of UC's Bancroft Library and Diane Rose of the Department of History at UC Davis. If you are interested in dealing with California cartography and associating with like-minded people, contact Mr. Hoehn for more information about the new society and future meetings. His address is the Bancroft Library, University of California, Berkeley, Calif. 94720, telephone 415/642-3781.

Harvard Computer Mapping Software and Data Bases conference

The Laboratory for Computer Graphics and Spatial Analysis, Harvard University Graduate School of Design, is sponsoring a 6-day conference in July formidably titled, "An International Users Conference on Computer Mapping Sof tware and Data Bases: Application and Dissemination." Conference sessions will cover computer mapping 
applications, a software review, data base review, survey of thematic map design principles, and software and data base distribution and marketing.

The Laboratory will be publishing a series of conference newsletters in the coming months concerning the conference. To get on the mailing list, submit a paper, or round up more information about the conference, contact Allen Schmidt, Conference Chairman, Harvard Laboratory for Computer Graphics, 520 Gund kiall, 48 Quincy Street, Cambridge, Mass. 02138.

LIST OF MEETINGS AND CONVENTIIONS -- June to December 1978

Canadian Cartographic Association Annual Meeting

Special Libraries Association

International User's Conference on Computer Mapping Software and Data Bases

Ninth Technical Conference of the International Cartographic Assoc.

Second Circum-Pacific Conference on Energy and Mineral Resources

Urban and Regional Information Systems Association (URISA)

5th Canadian Symposium on Remote Sensing

Inter-Congress Symposium on New Technology for Mapping

ACSM/ASP Fall Technical Meeting

Geophysical Union Fall Meeting
Vancouver, British Columbia June $8-10$

Kansas City, Missouri June 11-14

Cambridge, Massachusetts July 23-28

washington, D.C. July 26-August 2

Honolulu, Hawai i

July 30-August 4

washington, D.C. August $6-10$

Victoria, British Columbia August 27-31

Ottawa, Ontario

October 2-6, 1978

Albuquerque, New Mexico October 2-6, 1978

San Francisco, California Lecember 4-8, 1978 
NCIC addresses.

National Cartographic Information Center U.S. Geological Survey 507 National Center Reston, Va. 22092

Eastern Mapping Center National Cartographic Information Center U.S. Geological Survey 536 National Center keston, Va. 22092

Mid-Continent Mapping Center

National Cartographic Information Center U.S. Geological Survey 1400 Independence Road Rolla, Mo. 65401

Rocky Mountain Mapping Center National Cartographic Infonnation Center U.S. Geological Survey Box 25046, Stop 504, Federal Center Denver, Colo. 80225

Western Mapping Center National Cartographic Information Center U.S. Geological Survey 345 Middlefield Road Menlo Park, Calif. 94025

National Space Technology Laboratories National Cartographic Information Center U.S. Geological Survey

Building 1100 NSTL Station, Hiss. 39529

EROS Data Center U.S. Geological Survey Sioux Falls, S.Dak. 57198
Gary W. North 703-860-6045 FTS $928-6045$

Frederick Lavery 703-860-6336 FTS 928-6336

william M. Voight 314-364-3680, ext. 107 FTS 276-9107

Fiaymond E. Hill 303-234-2326 FIS 234-2326

Lee,$W$. Aggers 415-323-8111, ext. 2427 FTS $467-2427$

Henry T'. Svehlak 601-688-3544 FTS 494-3544
Kent N. Swanjord 605-594-651l, ext. 507 FTS 784-7507 

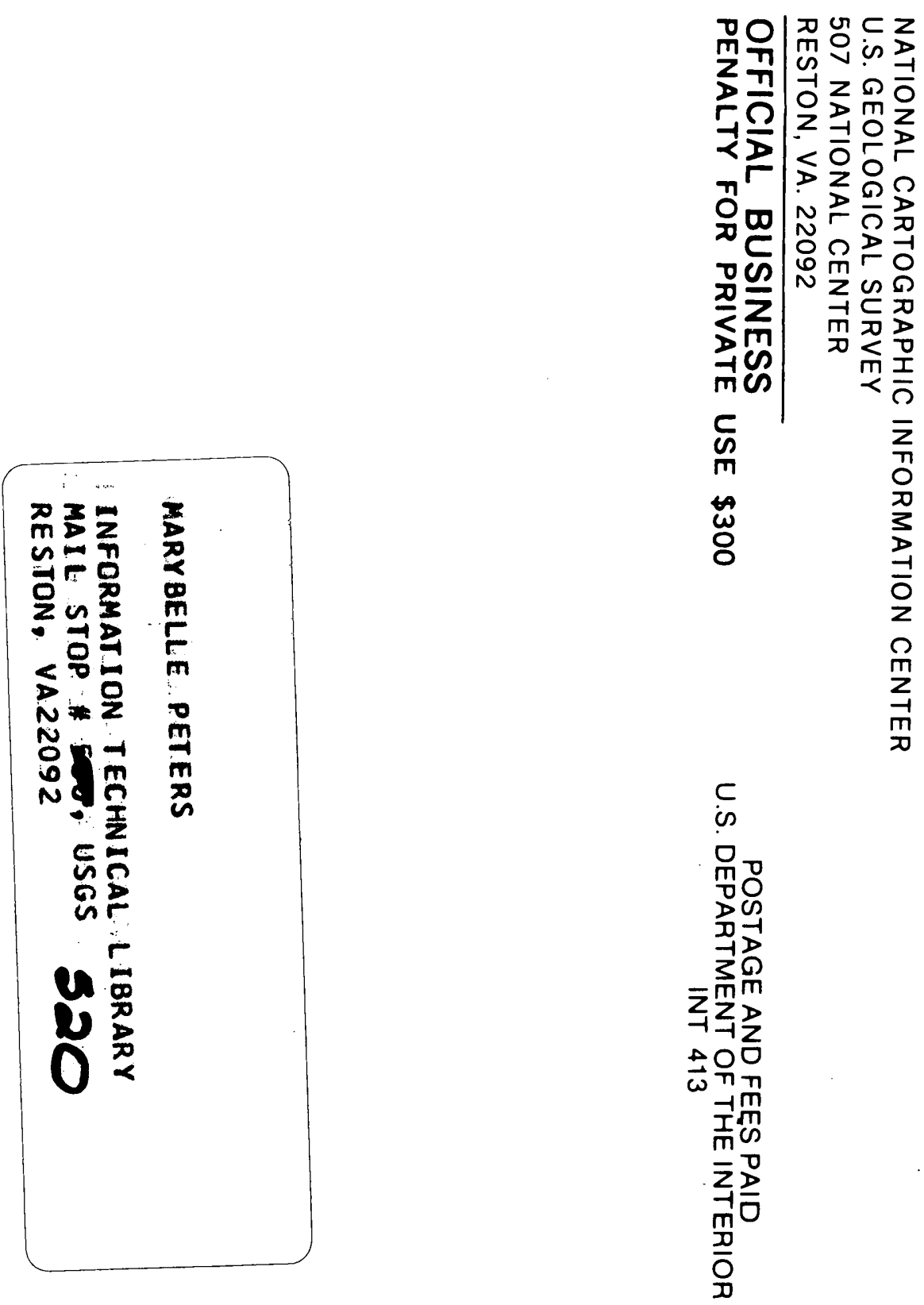

룰

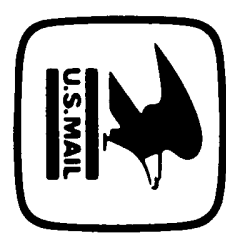

